prof.dr hab.inz. Krzysztof Magnucki

Politechnika Poznańska

Instytut Pojazdów Szynowych ,TABOR”

dr inz. Pawel Kuligowski

mgr inż. Marcin Kruś

Instytut Pojazdów Szynowych „,TABOR”

\title{
Pudła wagonów osobowych: wybrane zagadnienia
}

\begin{abstract}
W pracy scharakteryzowano rozwój budowy taboru wagonów osobowych na ziemiach polskich od drugiej połowy XIX wieku. Zwrócono szczególnq uwage na różnorodność wyposażenia i przeznaczenia wagonów pasażerskich, a także ewolucje konstrukcji nośnych od rozwiazań drewnianych do wspótczesnych stalowych cienkościennych. Praca jest realizowana $w$ ramach projektu rozwojowego $\mathrm{nr} R 10$ 0047/06/2009 „,Konstrukcja pojazdu szynowego z zastosowaniem najnowszych lekkich materiatów o wysokich parametrach wytrzymatościowych i o minimalnym oddziatywaniu na środowisko"
\end{abstract}

Problem transportu towarów i ludzi był mozolnie rozwiązywany przez stulecia. Podróżni przemieszczali się pieszo lub na zwierzętach po drogach-szlakach. Wozy, karety konne były podstawowym pojazdem w transporcie lądowym, których maksymalna prędkość była około $15 \mathrm{~km} / \mathrm{h}$. Znaczący postęp jest zauważalny dopiero $\mathrm{w}$ dziewiętnastym wieku. Zamiana napędu końskiego na silnik parowy oraz budowa dróg żelaznych miały decydujacy wpływ na znaczne zwiększenie prędkości podróży, a także masy przewożonych towarów na lądzie. Kolej zapoczątkowała rewolucję przemysłową w świecie. Tanel (2008) opisał historię kolei w układzie chronologicznym od lokomotyw parowych do kolei magnetycznych. Gawin (2010) wskazała na związek kolei z cywilizacją i nowoczesnością. Pierwsza linia kolejowa na świecie Stockton Darlington w Anglii została przekazano do eksploatacji w 1825 roku, a pięć lat później Liverpool - Manchester, która była wzorcem dla budowniczych następnych linii. Pociag z lokomotywą parową wywoływał radość i ciekawość wśród ludzi, stwarzał niestety również zagrożenie dla ich życia. Brak oswojenia ludzi i zwierząt z nowymi prędkościami przemieszczania się pojazdów był przyczyna licznych wypadków śmiertelnych. Intensywny rozwój kolejnictwa w drugiej połowie dziewiętnastego wieku odbywał się $\mathrm{w}$ większości krajów w świecie. W Europie w 1922 roku powołano Międzynarodowy Związek Kolei - UIC (Union Internationale des Chemins de fer) z siedzibą w Paryżu. UIC zrzesza przedsiębiorstwa transportu kolejowego i reprezentuje je w świecie, koordynuje współpracę między nimi w celu zwiększenia spójności systemów kolejowych różnych krajów oraz konkurencyjności w odniesieniu do transportu drogowego. UIC publikuje zarządzenia dotyczące technologii, infrastruktury i eksploatacji z uwagi na bezpieczeństwo. Polska należy do Międzynarodowego Związku Kolei, a więc budowany tabor spełnia kryteria sformułowane w odpowiednich Kartach UIC oraz raportach (Rp) i dokumentach technicznych (DT) opracowywanych przez jednostkę badawczą UIC (ORE-Office de Recherches et d'Essais przekształconą później w ERRIEuropean Rail Research Institute), a także normach europejskich (PN-EN) oraz przepisach TSI (Technical Specification for Interoperability).

Konstrukcje wagonów pasażerskich doskonalono wraz z rozwojem transportu kolejowego i zwiększaniem prędkości. Pierwsze wagony były odkryte analogiczne do pojazdów konnych. Doświadczenia zdobyte w ich eksploatacji wpływały na kształtowanie konstrukcji. Utworzono wiele fabryk produkujących tabor kolejowy. Zintel (1999) przypomniał o fabryce wagonów w Sanoku, która w latach 1891-1958 budowała tabor kolejowy, a w 1958 roku przekształcona została w Sanocka Fabrykę Autobusów. Niezwykle oryginalnym produktem tej fabryki, w początkowy okresie jej działalności, był wagon do przewozu zmarłych, którego zamówiło i eksploatowało Erste EisenbahnLeihwagengessellschaft Koenigswald w Wiedniu. Opisy konstrukcji pudeł wagonów osobowych są obszerne, zamieszczone w licznych opracowaniach przybliżają warunki podróżowania. Zintel (1997) przedstawił oryginalną konstrukcję wagonu restauracyjnego z klimatyzacją systemu Radowicza- chłodzenie lodem, którego zbudowano w latach 1914/15 dla linii Odessa-Kijów-Brześć nad Bugiem. Lód w okresie letnim był dostępny na większych stacjach z uwagi na wagony-lodówki do przewozu mięsa, mleka i owoców, zatem eksploatacja wagonu restauracyjnego nie sprawiała kłopotu. Pokropiński (1995) z okazji 150lecia kolei na ziemiach polskich scharakteryzowal krótko historię i tabor Drogi Żelaznej WarszawskoWiedeńskiej (DŻWW). Zaznaczył, że pierwszy pociąg osobowy odjechał z Warszawy do Grodziska 
Mazowieckiego w 1845 roku. Rozwój konstrukcji taboru kolejowego podzielił na trzy okresy: pierwszypoczątkowy (1840-57), drugi-średni (1858-1899) i trzeci-nowoczesny (1900-1915). Pierwsze pudła wagonów osobowych były drewniane, wzorowane na karetach konnych, ze sztywnymi zderzakami. Wagony pasażerskie DŻWW były produkowane w czterech klasach. Wagony pierwszej klasy składały się z odrębnych przedziałów ośmioosobowych z własnymi wejściami zewnętrznymi-bocznymi. Wagony drugiej klasy był podobne $\mathrm{z}$ dziesięcioosobowymi przedziałami. Siedzenia w tych wagonach były miękkie a przedziały ozdobione. Wagony trzeciej klasy były konstrukcjami otwartymi z dachem brezentowym i twardymi ławkami do siedzenia. Natomiast wagony czwartej klasy nie posiadały dachu, wyposażone były $\mathrm{w}$ twarde ławki ustawione wzdłuż ścian bocznych. Należy zaznaczyć, że pierwsze wagony pasażerskie nie były wyposażone w oświetlenie, ogrzewanie i toalety. W drugim okresie-średnim (1858-1899) zauważalny jest postęp w konstrukcjach wagonów, ostoje drewniane zastapiono stalowymi, wprowadzono zderzaki, sprzęgi, ogrzewanie, oświetlenie i toalety. Nowe wagony były bez przedziałów lub z przedziałami i korytarzem. Pod koniec drugiego okresu zaczęto wprowadzać hamulce zespolone na sprężone powietrze Westinghouse'a. W trzecim okresie-nowoczesnym DŻWW wprowadzono wagony cztero-osiowe typu Pullman produkowane w Rydze w latach 1895 - 1915 (Rys.1).

Kolejny znaczący postęp w budowie taboru kolejowego to wprowadzenie wózków. Wagony osobowe produkowane w kraju po II wojnie światowej posiadały wózki dwu-osiowe typu Görlitz, w później wersji 101A, oraz kolejne 4ANc, 7AN. Janiak i Kalinkowski (1974) opisali szczegółowo konstrukcje wagonów normalnotorowych. Przykładowe konstrukcje tych wagonów pokazano na Rys.2, które były produkowane przez H. Cegielski Poznań 1947 r., ZNTK Ostrów Wlkp. 1948 r., Pafawag Wrocław 1951 r.

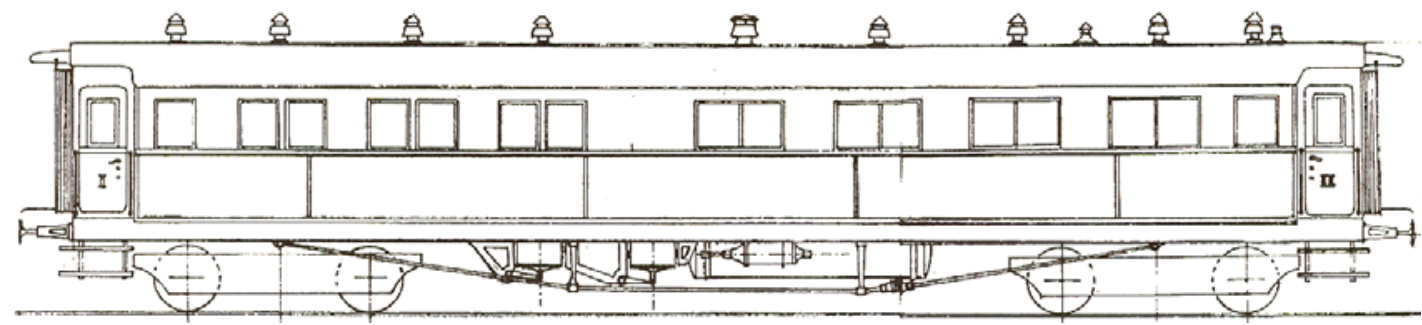

Rys.1. Wagon typu Pullman z lat 1895-1915 [Pokropiński (1995)]
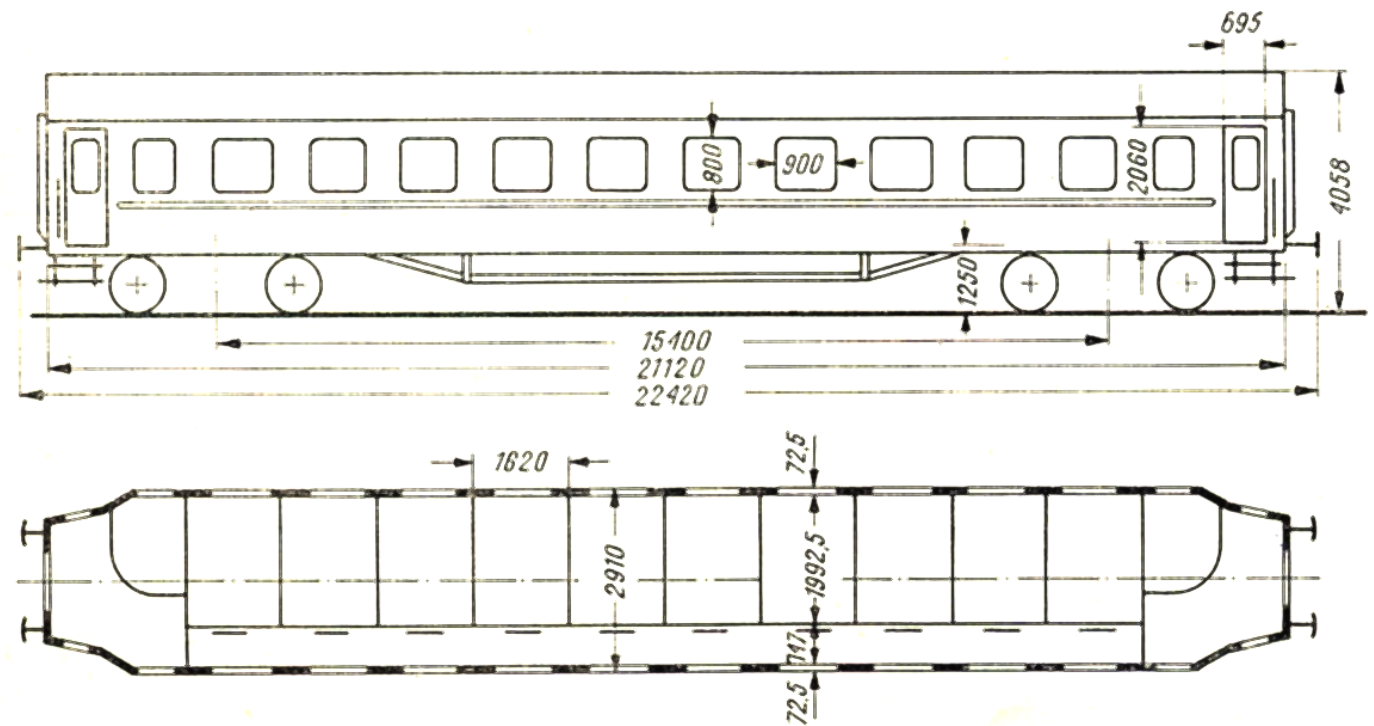

Rys.2. Wagon osobowy [Janiak i Kalinowski (1974)]

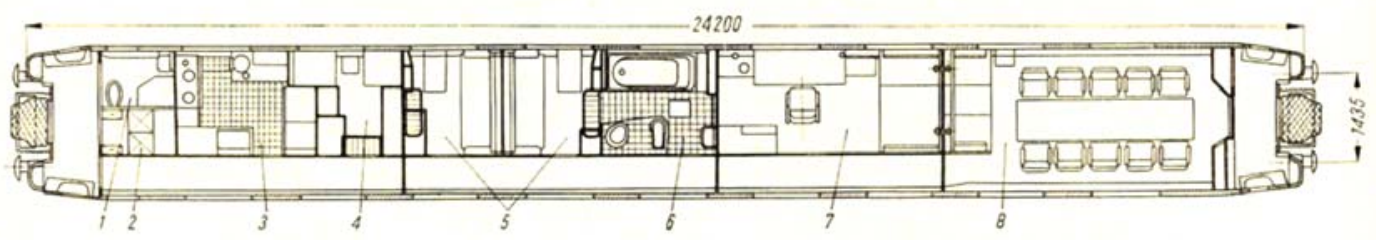

Rys.3. Wagon salonowy [Krzemieniecki (1976)] 
Produkowane były również wagony specjalnego przeznaczenia, np. salonowe, doświadczalne oraz techniczno-gospodarcze. Krzemieniecki (1976) opisał nadwozia i wyposażenie tego typu wagonów. Przykładowo, schemat konstrukcji wagonu salonowego typu 501A pokazano na Rys.5, gdzie oznaczono: 1- WC, 2kocioł, 3- kuchnię, 4- przedział służbowy, 5- przedziały sypialne, 6- łazienkę, 7- przedział mieszkalny, 8przedział konferencyjny.

Dobrowolski (1997) przedstawił historię rozwoju układów elektrycznych stosowanych w wagonach osobowych. Wskazał na znaczący udział tych urządzeń w wyposażeniu współczesnych wagonów. Zięba (1993) w obszernej monografii zebrał i opisał problemy kolei w latach 1945-1992 na obszarze Dyrekcji Okręgowej Kolei Państwowych w Poznaniu. Opisane wydarzenia przybliżają ciekawe czasy kolejnictwa po II wojnie światowej w Polsce. Durzyński (2011) wskazał na współczesne problemy taboru kolejowego. Etmanowicz i Koj (2010) przypomnieli historię niemieckich wagonów typu Mc4i-44 do przewozu osób z końca II wojny światowej, które służyły na PKP, jeszcze w latach pięćdziesiątych, jako wagony turystyczne (Rys 4).

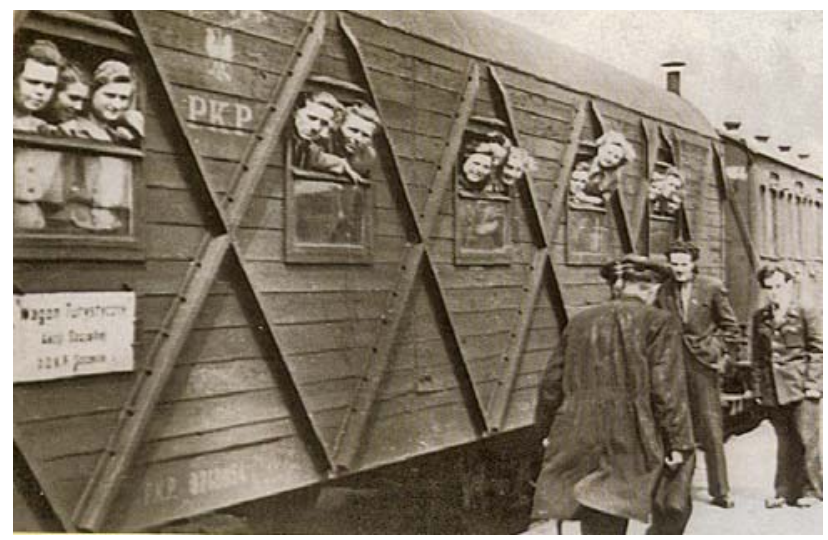

Rys.4. Wagon turystyczny [Etmanowicz i Koj (2010)]

Pudła wagonów osobowych są konstrukcjami cienkościennymi, które opisali zespół pod redakcją Szadura (1962), Neumann (1976), Krause i Meissner (1977), Kalinkowski i Orlik oraz Gąsowski (1988). Przykładowe przekroje pudeł wagonów pokazano na Rys. 5

Brzoska (1965) sformułował podstawy modelowania konstrukcji cienkościennych, których poznanie było niezbędne do poprawnego rozwiązania problemów wytrzymałości lub stateczności konstrukcji. Podstawowym narzędziem $\mathrm{w}$ obliczeniach do lat siedemdziesiątych była metoda sił, którą w kolejnych latach zastąpiła metoda elementów skończonych (MES). Współczesne modelowanie jest więc numeryczne. Konstruktor w projektowaniu korzysta z zakupionych systemów komputerowych - czarnych skrzynek. Należy zauważyć, że do poprawnego modelowania konstrukcji metodą elementów skończonych z zastosowaniem wybranego systemu komputerowego jest niezbędna znajomości mechaniki konstrukcji.

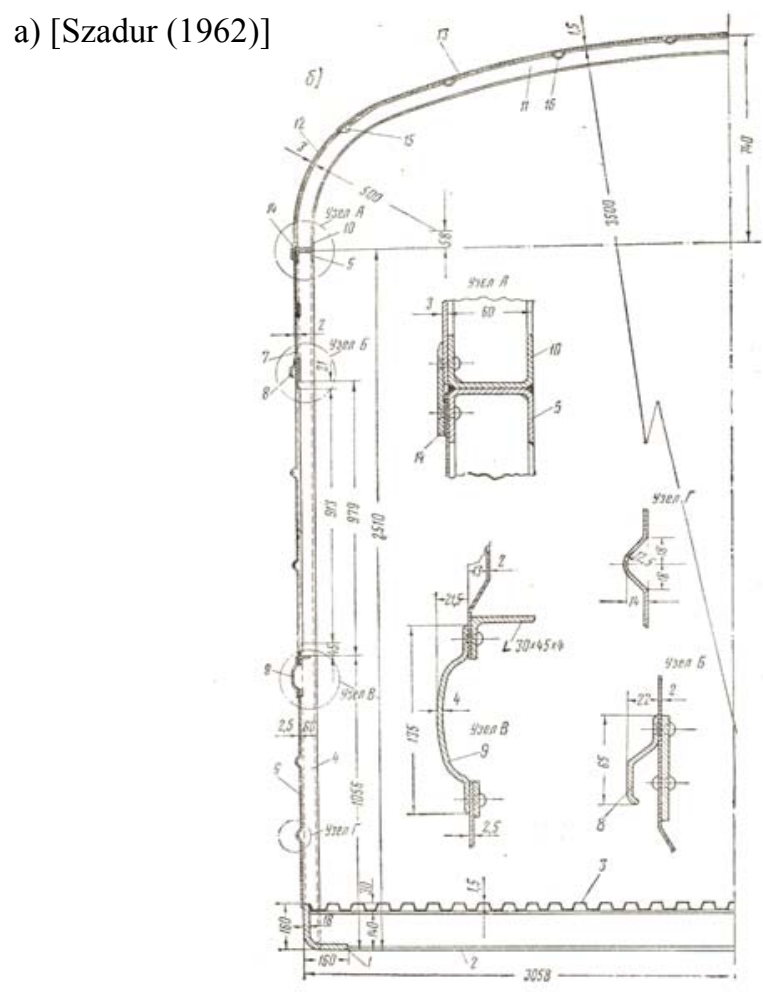

b) [Neumann (1976)]
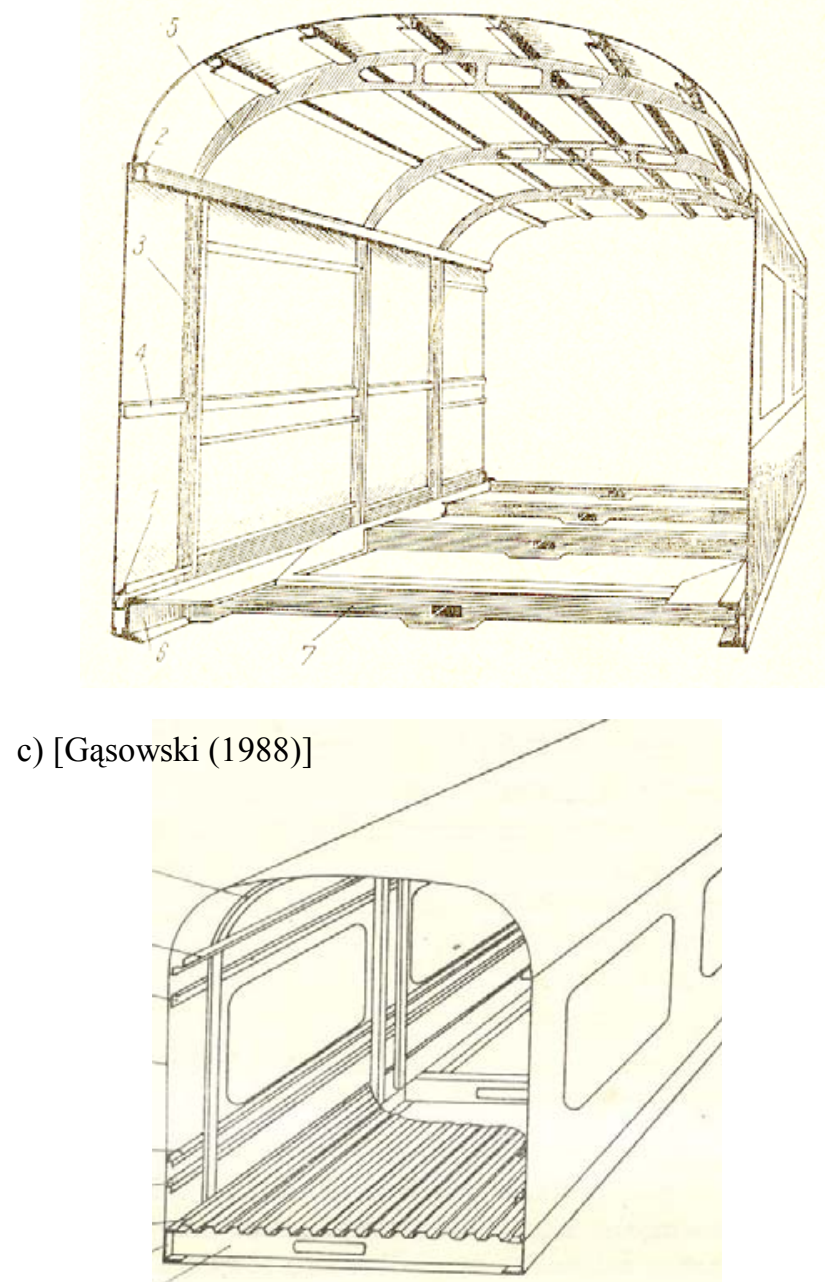

Rys.5. Cienkościenne przekroje pudeł wagonów osobowych 


\section{Literatura}

1. Brzoska Z., Statyka i stateczność konstrukcji prętowych i cienkościennych. PWN, Warszawa 1965.

2. Dobrowolski M., Historia rozwoju elektrycznych uktadów wagonowych w Polsce. Technika Transportu Szynowego, 3, 1997, 7-22.

3. Durzyński Z., Co dalej z polskim taborem kolejowym? Przeglad Handlowy, 325, kwiecień 2011.

4. Etmanowicz A., Koj K., Wagon niemiecki typu Mc4i-44 na PKP. Świat kolei, 7, 2010, 54-59.

5. Gawin M., Koleje kolei. Wiedza i Życie, 11, 2010, 4247.

6. Gasowski W., Wagony kolejowe. Konstrukcja i badania. Wyd. Komunikacji i Łaczności, Warszawa 1988.

7. Janiak M., Kalinkowski A., Normalnotorowe wagony PKP. Opisy $i$ charakterystyki technicznoeksploatacyjne. Wyd. Komunikacji i Łaczności, Warszawa 1974.

8. Jerczyński M., Wagon motorowy ESCix 90 011. Świat kolei, 3, 1998, 18-23.

9. Kalinkowski A., Orlik A., Wagony kolejowe i hamulce. Wyd. Komunikacji i Łaczności, Warszawa 1985.

10. Krause R., Meissner R., Wagony spalinowe. Seria SN 61. Wyd. Komunikacji i Łaczności, Warszawa 1977.

11. Krzemieniecki A., Tabor kolejowy. Wyd. Komunikacji $i$ Łaczności, Warszawa 1976.

12. Neumann T., Wagony $i$ hamulce kolejowe. Wyd. Komunikacji i Łączności, Warszawa 1976.
13. PN-EN 12663-1. Kolejnictwo - Wymagania konstrukcyjno-wytrzymatościowe dotyczace pudet kolejowych pojazdów szynowych - Czesść 1: Lokomotywy i tabor pasażerski. PKN, Warszawa 2010.

14. okropiński B., Tabor drogi żelaznej WarszawskoWiedeńskiej. Świat kolei, 2, 1995, 22-27.

15. Pokropinski B., Wagony osobowe typu Wernigerode Warszawskich Kolei Dojazdowych. Świat kolei, 6, 1999, 27-28.

16. Шадура Л.А., (Ред.) Конструкиии вагонов. Всесоюзное Изд. Москва 1962.

17. Tanel F., Historia kolei. Od lokomotyw parowych do kolei magnetycznych. Wydanie polskie: Carta Blanca, Grupa Wydawnicza PWN, Warszawa, 2008. Wydanie oryginalne: Trains, from steam locomotives to highspeed rail. White Star s.p.a. 2007, Vercelli, Italia.

18. UIC-Kodex 567. Allgemeine Bestimmungen für Reisezugwagen. UIC, 2004.

19. Zięba H., Monografia Dyrekcji Okręgowej Kolei Państwowych w Poznaniu: okres 1945-1992. ZDOKP Poznań, 1993.

20. Zintel K., Wagon z klimatyzacja Radowicza z 1915. Świat kolei, 1, 1997, 32-34.

21. Zintel K., Fabryka wagonów w Sanoku. Świat kolei, 1, 1999, 16-19. 